\title{
Failure Analysis in Photovoltaic Power Systems Using Artificial Neural Network
}

\author{
Mohamed R. Aboelmagd ${ }^{1, *)}$ \\ Ahmed A. Zaki Diab ${ }^{2)} \quad$ Gamal M. Dousoky $^{3)}$ \\ ${ }^{1)}$ Electrical Engineering Dept., Nahda University, New Beni Suef 62513, Egypt \\ ${ }^{2)}$ Electrical Engineering Dept., Minia University, Minia 61517, Egypt \\ ${ }^{3)}$ Dept. of Electrical and Electronic Engineering, Kyushu University, Fukuoka 819-0395, Japan \\ ${ }^{*}$ E-mail: mohamed.aboelmagd@nub.edu.eg
}

\begin{abstract}
:
As a result of the rapid expansion of photovoltaic systems, raising efficiency and managing maintenance became the PV systems' main factors. After that comes the cost and the time of repair immediately. This research provides an artificial neural network (ANN) to classify the system's type of failure. Three types of failure have been studied: line-to-line fault with a small voltage difference, a line-to-line fault with a large voltage difference, and ground fault. In addition to the fourth normal operation case, no failure is applied. The ANN employs five input data: power, voltage, current, temperature, and solar radiation. The output is a number from (0 to 3), each number denotes a specific type of failure: number ' 0 ' denotes the normal operation, number ' 1 ' denotes a line to line fault with a small voltage difference, number '2' denotes a ground fault, and number ' 3 ' denotes a line to line fault with a large voltage difference. Samples of collected data are used to train the ANN, with MATLAB Software Package, to model and simulate the system. Then, the proposed ANN is tested. Its ability to detect and classify the type of failure in the system is validated at a satisfactory success rate. The research's focus was on the discovery of a failure in the PV system, Not only the existence of a failure but also the discovery of the type of failure that occurred; this helps in speeding up the solution of the problem, speeding maintenance, and reducing the loss of power.
\end{abstract}

Keywords: Photovoltaic system, PV fault, the line-to-line fault, ground fault, PV faults simulation.

\section{INTRODUCTION:}

The emergence of the oil crises in the seventies has driven a major role in the development as the global PV industry developed at a rate with an average between $15 \%$ to $20 \%$ per year between 1991 to 2007 [1].

Received:10 Novamber, 2020, Accepted:27 March, 2021
This tremendous development had great competition in the semiconductor and computer industry between 2000 and 2009. The growth of photovoltaic energy increased from 1428 to 22,893 megawatts at an average rate of $36.7 \%$ annually, making it the fastest-growing energy technology in the world [2]. The tremendous growth was mainly for preserving the environment, reducing pollution, and making it a clean environment [3-4]. 


\section{Vol. 41, No.2. July 2022}

The development of devices and different manufacturing methods had a tremendous role in raising solar cells' efficiency and reducing the size. With advanced manufacturing methods, the value per watt decreased from 16 US dollars to 8 US dollars per watt in 2007 [1].

Plans for solar energy produced by the International Energy Agency are estimated to provide photovoltaic energy, about $11 \%$ of global electricity generation by 2050 . They will reduce 2.3 gigatonnes of carbon dioxide emissions annually. The result is that the photovoltaic industry plays an essential role in electricity. The result is in the future [5-6]. Energy stations by 2030, including ten solar power stations. Some stations may produce 600 megawatts [7].

Countries have a useful role in the development of the photovoltaic energy industry. The Arab Republic of Egypt had a role in constructing solar energy stations and other renewable energy stations. Still, solar energy stations had the most considerable role and the highest concentration. Many stations were established that help produce electricity significantly from general productivity; Egypt plans to establish 25 new and renewable.

Table 1 Planned PV projects up to 2030 [7]

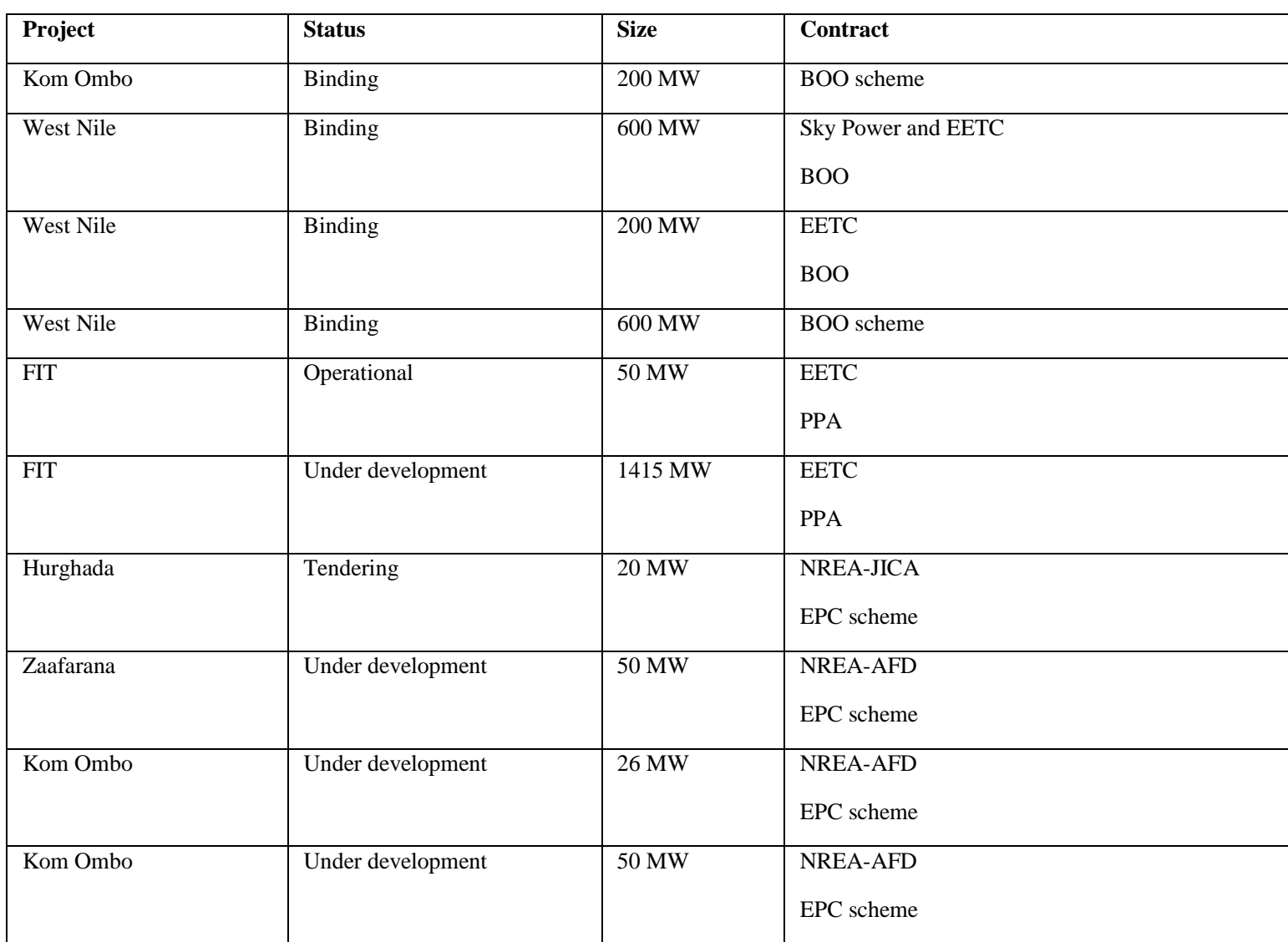

As a result of the heavy use of photovoltaic panels, the failure of photovoltaic components increased. This failure is due to many reasons such as short circuit, open circuit, dust, and the derivation of photoelectric cells and shade. Failures affect the operating efficiency of the PV power generation system. Improving the performance of the photovoltaic system requires the absence of any system failure. The failure can be classified into temporary failure and permanent fault in the photoelectric arrays. Both of which reduce the efficiency of the PV energy system. One of the 
methods of failure detection is monitoring and analysis of the system. It collects primary data from the system at its normal operation state (no failure), such as voltage, current, power, and curve measurements, which give an overview analysis of the health system. The model and simulation must be able to produce the conclusion of similar behaviors to artificial intelligence systems. Artificial intelligence networks have many forms that differ in terms of construction and interconnection of networks with some. Modifications are made to the neural networks and trained to be consistent with the input data. The neural network is the result of the comparison between input and output. Therefore, there must be a comprehensive program to detect the failure and detect the type of failure because some programs only discover the failure. Still, this program is designed to discover the type of failure to reduce the repair time. The employed system here is an Artificial Neural Network (ANN) based system.

Among the most common concerns about solar energy are faults, inaccuracies in solar energy matrices, and failure during conduction. As a result of faults, several risks occur, such as electric shock and fire exposure, efficiency decrease, and even power outage. In this work, three types of failure have been studied: line to line fault with a small voltage difference, a line to line fault with a large voltage difference, and ground fault, In addition to the fourth normal fault, where no failure is applied. The research sheds light on discovering the photoelectric system's failure and determining the type of failure that occurs through the neural network. Matlab/Simulink is used to model the photoelectric system and apply the neural network to discover the type of failure. It had highefficiency results, and determining the type of failure helps in the speed and eases of solving the system Maintenance and reduced power loss.

\section{PV SYSTEM DESCRIPTION}

The solar PV system includes various components that must be calculated and determined according to the consumption of electrical appliances, storage, solar cells, and the solar system's location and available area to be covered by PV panels. Fig. 1 shows a block diagram of the typical stand-alone PV power system. It can be described as follows:

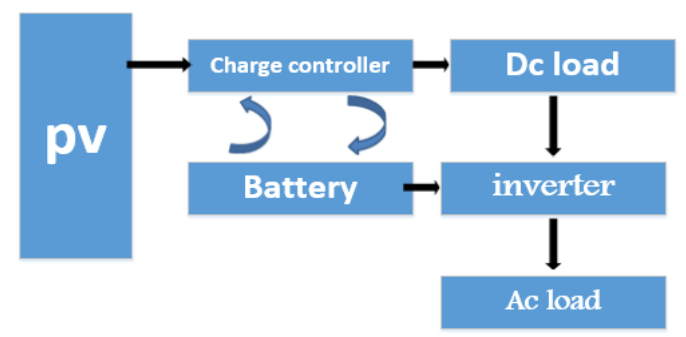

Fig. 1: Block diagram of the typical stand-alone PV power system.

\subsection{PV modules:}

Solar cells are made of semiconductors, and their function is to convert the light produced by the sun into DC electricity. Fig. 2 shows a single-diode model of solar cells [8].

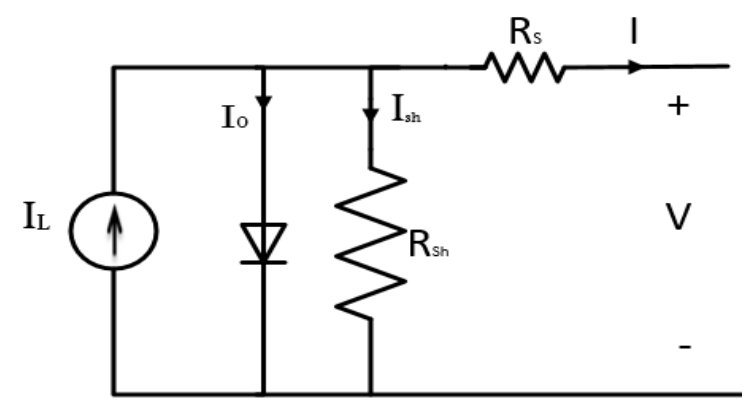

Fig. 2 Single-diode model of solar cell

Such PV model can be represented by the following equation [8]:

$I_{L}-I_{S}\left[\exp \left(\frac{\left(1+R_{S}\right)}{A K T} q\right)-1\right]-\left(\frac{\left(V+I R_{S}\right)}{R_{P}}\right)(1)$

Where, $I=$ solar cell current $(\mathrm{A}), V=$ solar cell voltage $(\mathrm{V}), I_{L}=$ light-generated current $(\mathrm{A}), I_{S}=$ saturation current of the diode $(\mathrm{A}), R_{S}=$ solar cell series resistance (ohms), $R_{P}=$ solar cell shunt 
resistance $($ ohms $), q$ (electron charge $)=1.6 \times 10-$ $19 \mathrm{C}, K=$ Boltzmann's constant $=1.38 \times 10-23$ $\mathrm{J} / \mathrm{K}, A=$ diode ideality factor $(1 \leq A \leq 2), T=$ ambient temperature $(\mathrm{K})$. Depending on solar irradiance and ambient temperature, the light generated current $I_{L}$ is described as [8]:

$$
I_{L}=\left(\frac{G}{G_{0}}\right)\left[I_{L_{0}}+C_{T}\left(T-T_{0}\right)\right]
$$

Where, $G=$ solar irradiance $\left(\mathrm{W} / \mathrm{m}^{2}\right), G_{0}=$ reference solar irradiance $\left(\mathrm{W} / \mathrm{m}^{2}\right)=$ reference light generated current (A), $T_{0}=$ reference temperature $(\mathrm{K}), C_{T}=$ temperature coefficient of the light generated current $(\mathrm{A} / \mathrm{K})$. Furthermore, the saturation current $I_{S}$ of the diode is varying with the temperature, as follows [8]:

$$
I_{S}=I_{S_{0}}\left(\frac{T}{T_{0}}\right)^{3} \exp \left[\frac{q E_{G}}{A K}\left(\frac{1}{T_{0}}-\frac{1}{T}\right)\right]
$$

Where $E \mathrm{~g}$ is the bandgap energy of the material $(\mathrm{eV})$

\section{SIMULATION OF PV SYSTEM}

The photovoltaic array usually consists of several solar cells identical in characteristics and specifications to fulfill load demand. The voltage and current are determined at the maximum and highest PowerPoint of operation. Geography, temperature, and solar radiation level vary, and the level of solar radiation is the main input for the solar cells. Furthermore, some other factors may affect the photovoltaic system operation, such as failures that significantly impact reducing the energy output of the PV system.
After attempts to design a photovoltaic power system under normal working conditions and operating conditions where a particular failure occurs, a Matlab program was designed to carry out simulations, extract results, and apply the studied cases to the photovoltaic array.

The solar cells were carefully studied, and during the design, the temperature and the level of solar radiation were taken as inputs, whether current, volts, and power as outputs.

Failure operating cases are applied to the PV array, and both current and voltage are identified. The same type of cells and the exact specifications and features are used in the PV array.

Table 2 illustrates the used PV module data, including maximum power, open-circuit voltage, the voltage at the maximum power point, number of cells in a module, short circuit current, current at the maximum power point, and temperature coefficient for voltage and current [8].

Table 2: Module data of PV array

\begin{tabular}{|c|c|}
\hline $\begin{array}{c}\text { Maximum Power } \\
(\mathrm{W})=83.2824\end{array}$ & $\begin{array}{c}\text { Cells per module (No. } \\
\text { cell })=60 / 3\end{array}$ \\
\hline $\begin{array}{c}\text { Open circuit voltage } V_{o c} \\
(\mathrm{~V})=12.64\end{array}$ & $\begin{array}{c}\text { Short-circuit current } I_{s c} \\
(\mathrm{~A})=8.82\end{array}$ \\
\hline The voltage at maximum & Current at maximum power \\
power point $V_{m p}(\mathrm{~V})=10.32$ & point $I_{m p}(\mathrm{~A})=8.07$ \\
\hline Temperature coefficient of & Temperature coefficient of \\
$V_{o c}(\% /$ deg.C $)=0.33969$ & $I_{s c}(\% /$ deg $\mathrm{C})=0.063701$ \\
\hline
\end{tabular}

\subsection{Simulation of the normal condition}

PV system model is built using MATLAB Simulink, and the model is tested for various operating conditions. Results are drowning in 
curves, which are mainly based on the fault under the PV system study. As shown in Fig. 3, sixteen PV panels are connected in a series/parallel combination, where no failure is applied. The test is carried out in more than one point/line in the system

\subsection{Simulation of Line to Line Fault (small} voltage difference)

Inline to small line voltage is simulated by creating a short circuit between the strings of PV modules. As shown in Fig.4, a short circuit is applied between solar cells no. (1-2) and solar cells no. (67). A line-to-line voltage is considered a short circuit that causes the PV system modules' power to decrease dramatically [9].

\subsection{Simulation of Line to Line Fault (large voltage difference)}

The inline line-to-line fault with a large voltage difference is simulated by creating a short circuit between PV modules' strings. As shown in Fig. 5, the fault is applied by connecting a short circuit between solar cells. (1-2) and solar cells no. (7-8) such line-to-line voltage causes the power of the PV system modules to decrease dramatically.

\subsection{Simulation of Ground Fault}

As shown in Fig. 6, a ground fault is applied. A ground fault is the most prevalent type between faults of PV systems. With this fault, current flow occurs through the ground conductor before reaching the inverter, and it causes many problems to the system that may lead to fires [10-11].

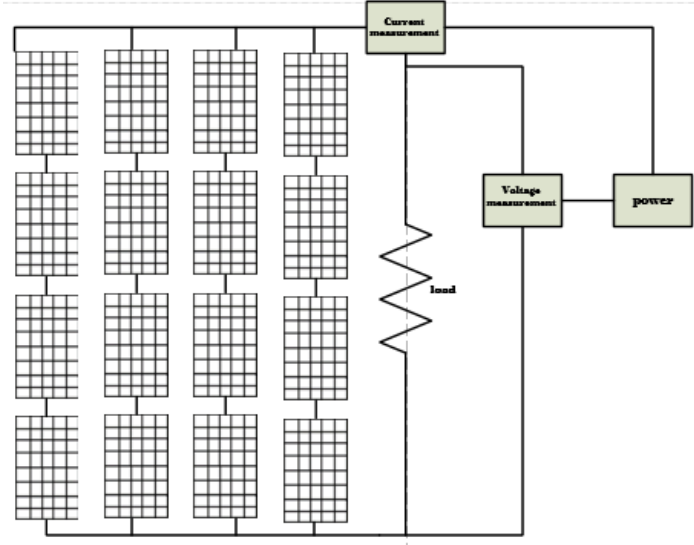

Fig.3 PV system at the normal operating condition.

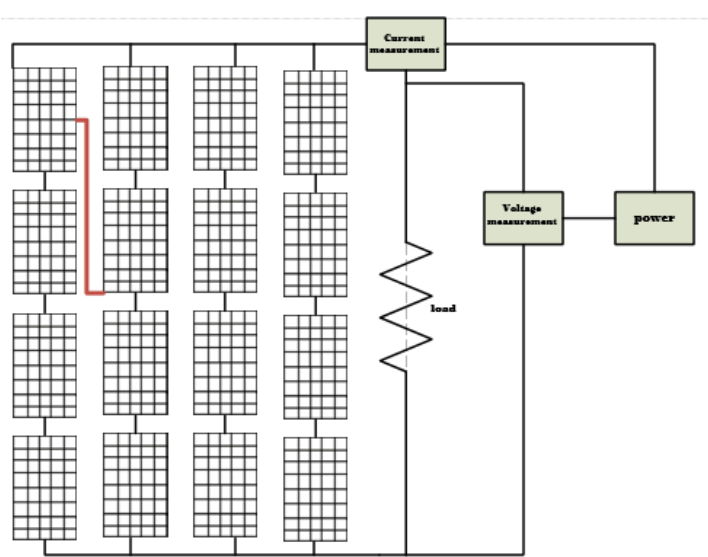

Fig.4 PV system with a line-to-line fault (small voltage difference).

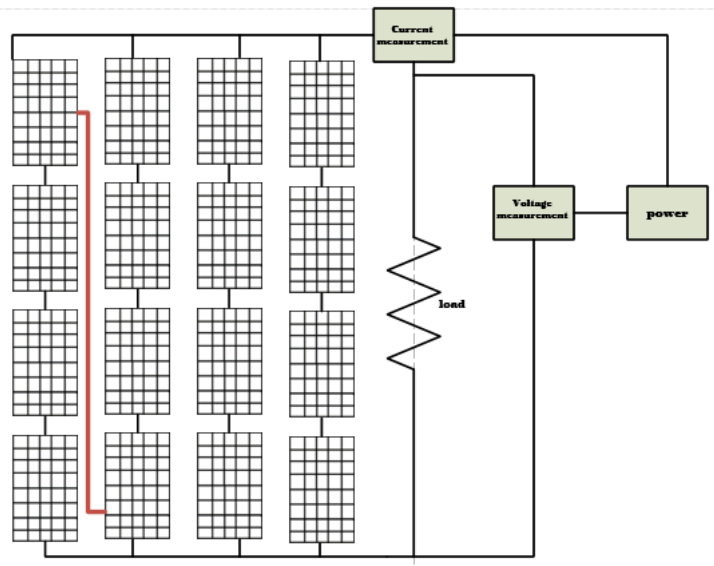

Fig.5 PV system with a line-to-line fault (large voltage difference). 


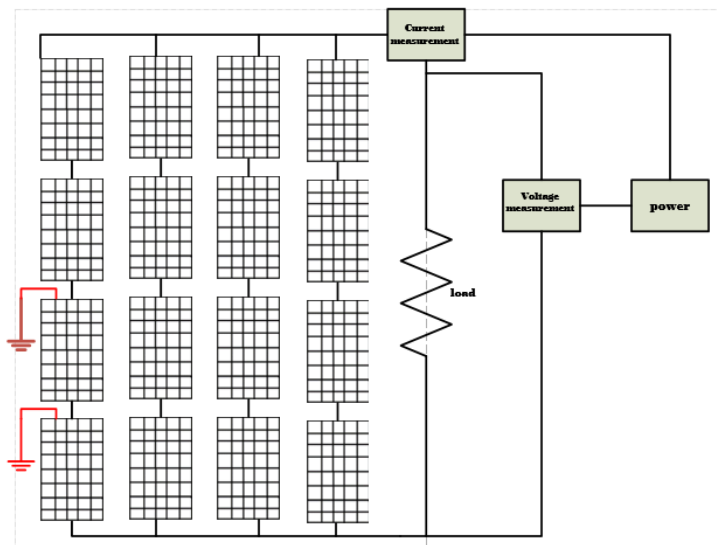

Fig.6 PV system with ground fault

\section{DATA COLLECTION}

After simulating the PV arrays and testing various faults, the next step is data collection for every type of fault and comparing the three outputs (currentvoltage-power). The data has been collected as illustrated in the following tables (Table 3 to Table 6). Tables include measured quantities at the maximum power point (voltage, current, and power) in various cases (normal operation, the line to line fault with small voltage, the line to line fault with large voltage, and ground fault) and at different solar radiation/temperature. Furthermore, PV curves help to detect the failure occur in the PV energy systems. [12].

\section{PROPOSED ANN BASED FAULT DETECTION SYSTEM}

\subsection{Design of the Artificial Neural Network}

Artificial intelligence networks (ANNs) have many forms that may differ in terms of construction and interconnection of neurons.

ANN modeling and simulation should be able to create similar behaviors in industrial systems. ANN works by processing the information and presenting the information in the form of mutations. The ANN consists of a group of neurons (as shown in Fig. 7) connected according to a specific shape and the formation of an organized architectural way [13],[14].

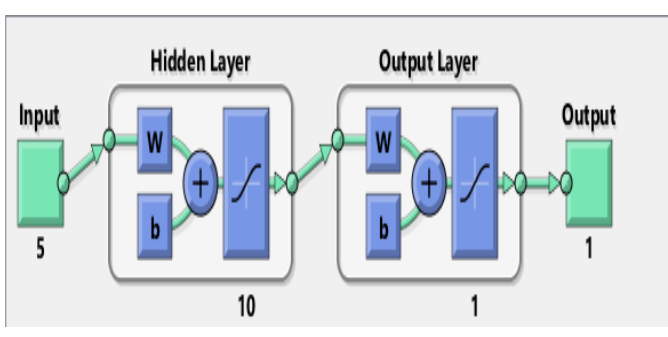

Fig. 7 Structure of a typical artificial neural.

The recorded data are split into two subsets: a training data set $(70 \%$ of patterns, a sample is addressed in Table 7), which is used to evaluate the gradient and to readjust the network weights and bias, and a test set (the other $30 \%$ patterns). The latter set is used to validate the Multi-Layer Perceptron model by comparing the actual data with the estimated output.

\subsection{Fault Classification}

A fault detection model is developed using an ANN. The ANN model consists of five inputs: temperature, irradiance, maximum voltage, maximum current, and maximum power. It has one output: fault number, as shown in Fig. 8. The single output is a number, and this number denotes the fault type is addressed in Table 8. The table illustrates the output corresponding to the type of fault. Hence, it is easier to identify the type of failure more easily and quickly, making the modeling process easier [15], [16].

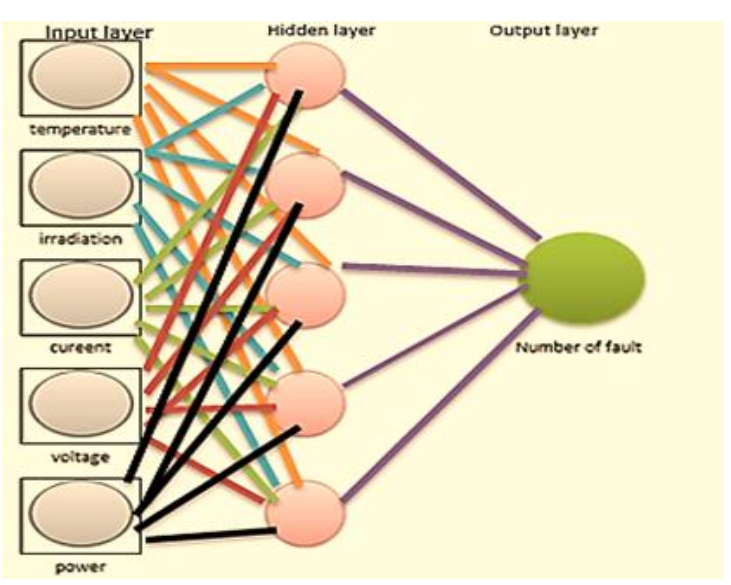

Fig.8 Proposed ANN-based fault detector. 
Vol. 41, No.2. July 2022

Table 8. The output corresponding to the type of

fault

\begin{tabular}{|l|c|}
\hline \multicolumn{1}{|c|}{ Type of fault } & number \\
\hline Normal operation & 0 \\
\hline Line to line with a small voltage difference & 1 \\
\hline Ground fault & 2 \\
\hline Line to line with a large voltage difference & 3 \\
\hline
\end{tabular}


Vol. 41, No.2. July 2022

Table 3. Data collected at solar irradiance of $1000 \mathrm{~W} / \mathrm{m}^{2}$

\begin{tabular}{|c|c|c|c|c|c|c|c|c|c|c|c|c|}
\hline Temperature & $\begin{array}{l}I_{m}(\text { normal } \\
\text { operation) }\end{array}$ & $\begin{array}{c}I_{m}(\mathrm{~L}-\mathrm{L} \text { with } \\
\text { small voltage } \\
\text { difference) }\end{array}$ & $\begin{array}{c}I_{m}(\mathrm{~L}-\mathrm{L} \text { with } \\
\text { large voltage } \\
\text { difference) }\end{array}$ & $\begin{array}{c}I_{m} \text { (ground } \\
\text { fault) }\end{array}$ & $\begin{array}{l}V_{m}(\text { normal } \\
\text { operation) }\end{array}$ & $\begin{array}{c}V_{m}(\mathrm{~L}-\mathrm{L} \text { with } \\
\text { small voltage } \\
\text { difference })\end{array}$ & $\begin{array}{c}V_{m} \text { (L-L with } \\
\text { large voltage } \\
\text { difference) }\end{array}$ & $\begin{array}{l}V_{m} \text { (ground } \\
\text { fault) }\end{array}$ & $\begin{array}{c}P_{m} \text { (normal } \\
\text { operation) }\end{array}$ & $\begin{array}{c}P_{m}(\mathrm{~L}-\mathrm{L} \\
\text { with small } \\
\text { voltage } \\
\text { difference }) \\
\end{array}$ & $\begin{array}{c}P_{m}(\mathrm{~L}-\mathrm{L} \text { with } \\
\text { large voltage } \\
\text { difference) }\end{array}$ & $\begin{array}{c}P_{m} \text { (ground } \\
\text { fault) }\end{array}$ \\
\hline 20 & 32.2277 & 32.0439 & 32.1359 & 32.0401 & 42.1670 & 34.3555 & 22.9290 & 34.3302 & 1.3589 & 1.1009 & 736.8438 & 1.0999 \\
\hline 25 & 32.2866 & 32.0871 & 32.1518 & 32.0699 & 41.2696 & 33.7362 & 22.5371 & 33.7235 & 1.3325 & 1.0825 & 724.6084 & 1.0815 \\
\hline 30 & 32.3239 & 32.1154 & 32.1837 & 32.0962 & 40.3974 & 33.1294 & 22.1326 & 33.1168 & 1.3058 & 1.0640 & 712.3094 & 1.0629 \\
\hline 35 & 32.3691 & 32.1406 & 32.2139 & 32.1314 & 39.5126 & 32.5227 & 21.7282 & 32.4974 & 1.2790 & 1.0453 & 699.9479 & 1.0442 \\
\hline 40 & 32.4021 & 32.1623 & 32.2233 & 32.1501 & 38.6405 & 31.9160 & 21.3363 & 31.8907 & 1.2520 & 1.0265 & 687.5262 & 1.0253 \\
\hline 45 & 32.4536 & 32.1932 & 32.2498 & 32.1903 & 37.7430 & 31.2966 & 20.9318 & 31.2587 & 1.2249 & 1.0075 & 675.0476 & 1.0062 \\
\hline
\end{tabular}

Table 4. Data collected at an irradiance of $800 \mathrm{~W} / \mathrm{m}^{2}$

\begin{tabular}{|c|c|c|c|c|c|c|c|c|c|c|c|c|}
\hline Temperature & $\begin{array}{c}I_{m}(\text { normal } \\
\text { operation) }\end{array}$ & $\begin{array}{c}I_{m}(\mathrm{~L}-\mathrm{L} \text { with } \\
\text { small } \\
\text { voltage } \\
\text { difference })\end{array}$ & $\begin{array}{c}I_{m}(\mathrm{~L}-\mathrm{L} \text { with } \\
\text { large voltage } \\
\text { difference })\end{array}$ & $\begin{array}{c}I_{m} \text { (ground } \\
\text { fault) }\end{array}$ & $\begin{array}{l}V_{m} \text { (normal } \\
\text { operation) }\end{array}$ & $\begin{array}{c}V_{m}(\mathrm{~L}-\mathrm{L} \\
\text { with small } \\
\text { voltage } \\
\text { difference })\end{array}$ & $\begin{array}{c}V_{m}(\mathrm{~L}-\mathrm{L} \\
\text { with large } \\
\text { voltage } \\
\text { difference })\end{array}$ & $\begin{array}{c}V_{m} \text { (ground } \\
\text { fault) }\end{array}$ & $\begin{array}{c}P_{m} \text { (normal } \\
\text { operation) }\end{array}$ & $\begin{array}{c}P_{m}(\mathrm{~L}-\mathrm{L} \\
\text { with small } \\
\text { voltage } \\
\text { difference })\end{array}$ & $\begin{array}{c}P_{m}(\mathrm{~L}-\mathrm{L} \text { with } \\
\text { large voltage } \\
\text { difference) }\end{array}$ & $\begin{array}{c}P_{m} \text { (ground } \\
\text { fault) }\end{array}$ \\
\hline 20 & 19.3768 & 19.3711 & 19.4302 & 19.3559 & 42.3440 & 34.1406 & 22.7773 & 34.1406 & 820.4920 & 661.3434 & 442.5677 & 660.8217 \\
\hline 25 & 19.4178 & 19.3971 & 19.4536 & 19.3958 & 41.4213 & 33.5086 & 22.3602 & 33.4834 & 804.3114 & 649.9718 & 434.9850 & 649.4376 \\
\hline 30 & 19.4397 & 19.4216 & 19.4757 & 19.4046 & 40.5365 & 32.8766 & 21.9430 & 32.8766 & 788.0186 & 638.5158 & 427.3568 & 637.9587 \\
\hline 35 & 19.4726 & 19.4443 & 19.4967 & 19.4337 & 39.6264 & 32.2446 & 21.5259 & 32.2320 & 771.6290 & 626.9750 & 419.6851 & 626.3866 \\
\hline 40 & 19.4982 & 19.4652 & 19.5166 & 19.4610 & 38.7290 & 31.6126 & 21.1088 & 31.5874 & 755.1435 & 615.3468 & 411.9712 & 614.7217 \\
\hline 45 & 19.5224 & 19.4842 & 19.5352 & 19.4784 & 37.8315 & 30.9806 & 20.6917 & 30.9554 & 738.5627 & 603.6345 & 404.2163 & 602.9599 \\
\hline
\end{tabular}


Vol. 41, No.2. July 2022

Table 5. Data collected at an irradiance of $600 \mathrm{~W} / \mathrm{m}^{2}$

\begin{tabular}{|c|c|c|c|c|c|c|c|c|c|c|c|c|}
\hline Temperature & $\begin{array}{l}I_{m}(\text { normal } \\
\text { operation) }\end{array}$ & $\begin{array}{l}I_{m}(\mathrm{~L}-\mathrm{L} \\
\text { with small } \\
\text { voltage } \\
\text { difference })\end{array}$ & $\begin{array}{l}I_{m}(\mathrm{~L}-\mathrm{L} \text { with } \\
\text { large voltage } \\
\text { difference) }\end{array}$ & $\begin{array}{l}I_{m} \text { (ground } \\
\text { fault) }\end{array}$ & $\begin{array}{l}V_{m} \text { (normal } \\
\text { operation) }\end{array}$ & $\begin{array}{l}V_{m}(\mathrm{~L}-\mathrm{L} \\
\text { with small } \\
\text { voltage } \\
\text { difference })\end{array}$ & $\begin{array}{l}V_{m}(\mathrm{~L}-\mathrm{L} \\
\text { with large } \\
\text { voltage } \\
\text { difference })\end{array}$ & $\begin{array}{l}V_{m} \text { (ground } \\
\text { fault) }\end{array}$ & $\begin{array}{l}P_{m} \text { (normal } \\
\text { operation) }\end{array}$ & $\begin{array}{l}P_{m}(\mathrm{~L}-\mathrm{L} \\
\text { with small } \\
\text { voltage } \\
\text { difference })\end{array}$ & $\begin{array}{l}P_{m}(\mathrm{~L}-\mathrm{L} \text { with } \\
\text { large voltage } \\
\text { difference) }\end{array}$ & $\begin{array}{l}P_{m} \text { (ground } \\
\text { fault) }\end{array}$ \\
\hline 20 & 25.8167 & 25.7318 & 25.8126 & 881.6886 & 42.3061 & 34.2923 & 22.8784 & 34.2797 & 1.0922 & 882.4042 & 590.5510 & 881.6886 \\
\hline 25 & 25.8526 & 25.7718 & 25.8350 & 25.7593 & 41.4213 & 33.6603 & 22.4739 & 33.6477 & 1.0708 & 867.4885 & 580.6136 & 866.7412 \\
\hline 30 & 25.8869 & 25.8002 & 25.8705 & 25.7863 & 40.5365 & 33.0410 & 22.0568 & 33.0283 & 1.0494 & 852.4624 & 570.6204 & 851.6785 \\
\hline 35 & 25.9274 & 25.8363 & 25.8897 & 25.8207 & 39.6390 & 32.4090 & 21.6523 & 32.3963 & 1.0277 & 837.3262 & 560.5731 & 836.4942 \\
\hline 40 & 25.9667 & 25.8598 & 25.9073 & 25.8420 & 38.7416 & 31.7896 & 21.2478 & 31.7770 & 1.0060 & 822.0711 & 550.4733 & 821.1808 \\
\hline 45 & 25.9874 & 25.8700 & 25.9388 & 25.8602 & 37.8694 & 31.1829 & 20.8307 & 31.1576 & 0.9841 & 806.7018 & 540.3232 & 805.7406 \\
\hline
\end{tabular}

Table 6. Data collected at irradiance of $400 \mathrm{~W} / \mathrm{m}^{2}$

\begin{tabular}{|c|c|c|c|c|c|c|c|c|c|c|c|c|}
\hline Temperature & $\begin{array}{l}I_{m} \text { (normal } \\
\text { operation) }\end{array}$ & $\begin{array}{l}I_{m}(\mathrm{~L}-\mathrm{L} \text { with } \\
\text { small voltage } \\
\text { difference) }\end{array}$ & $\begin{array}{l}I_{m}(\mathrm{~L}-\mathrm{L} \text { with } \\
\text { large voltage } \\
\text { difference })\end{array}$ & \begin{tabular}{|l|}
$I_{m}$ \\
(ground \\
fault)
\end{tabular} & $\begin{array}{l}V_{m} \text { (normal } \\
\text { operation) }\end{array}$ & $\begin{array}{l}V_{m}(\mathrm{~L}-\mathrm{L} \text { with } \\
\text { small voltage } \\
\text { difference) }\end{array}$ & $\begin{array}{l}V_{m}(\mathrm{~L}-\mathrm{L} \text { with } \\
\text { large voltage } \\
\text { difference })\end{array}$ & $\begin{array}{l}V_{m} \text { (ground } \\
\text { fault) }\end{array}$ & $\begin{array}{l}P_{m} \text { (normal } \\
\text { operation) }\end{array}$ & $\begin{array}{l}P_{m}(\mathrm{~L}-\mathrm{L} \\
\text { with small } \\
\text { voltage } \\
\text { difference })\end{array}$ & $\begin{array}{l}P_{m}(\mathrm{~L}-\mathrm{L} \text { with } \\
\text { large voltage } \\
\text { difference })\end{array}$ & $\begin{array}{l}P_{m} \text { (ground } \\
\text { fault) }\end{array}$ \\
\hline 20 & 12.9301 & 12.9510 & 12.9871 & 12.9411 & 42.1418 & 33.8499 & 22.5877 & 33.8499 & 544.8955 & 438.3903 & 293.3488 & 438.0545 \\
\hline 25 & 12.9496 & 12.9692 & 13.0057 & 12.9637 & 41.2317 & 33.2053 & 22.1579 & 33.1926 & 533.9345 & 430.6457 & 288.1801 & 430.3010 \\
\hline 30 & 12.9724 & 12.9863 & 13.0236 & 12.9804 & 40.3090 & 32.5606 & 21.7282 & 32.5480 & 522.9040 & 422.8427 & 282.9799 & 422.485 \\
\hline 35 & 12.9904 & 13.0023 & 13.0408 & 13.0009 & 39.3989 & 31.9160 & 21.2984 & 31.8907 & 511.8056 & 414.9818 & 277.7490 & 414.6071 \\
\hline 40 & 13.0074 & 13.0223 & 13.0573 & 13.0149 & 38.4888 & 31.2587 & 20.8686 & 31.2461 & 500.6410 & 407.0604 & 272.4882 & 406.6648 \\
\hline 45 & 13.0236 & 13.0412 & 13.0730 & 13.0328 & 37.5787 & 30.6014 & 20.4389 & 30.5888 & 489.4117 & 399.0789 & 267.1982 & 398.6574 \\
\hline
\end{tabular}


Vol. 41, No.2. July 2022

Table 7. Sample of the training data set for ANN

\begin{tabular}{|l|c|c|c|c|c|c|c|c|}
\hline Temperature & 20 & 20 & 25 & 25 & 30 & 30 & 45 \\
\hline Irradiation & 800 & 1000 & 800 & 1000 & 800 & 1000 & 600 & 400 \\
\hline$V_{\max }$ & 42.3061 & 42.167 & 33.6603 & 33.7362 & 33.0283 & 33.1168 & 20.6917 & 20.4389 \\
\hline$I_{\max }$ & 25.8167 & 32.2277 & 25.7718 & 32.0871 & 25.7863 & 32.0962 & 19.5352 & 13.073 \\
\hline$P_{\max }$ & $1.09 \mathrm{E}+03$ & $1.36 \mathrm{E}+03$ & 867.4885 & $1.08 \mathrm{E}+03$ & 851.6785 & $1.06 \mathrm{E}+03$ & 404.2163 & 267.1982 \\
\hline Fault No. & 0 & 0 & 1 & 1 & 2 & 2 & 3 \\
\hline
\end{tabular}

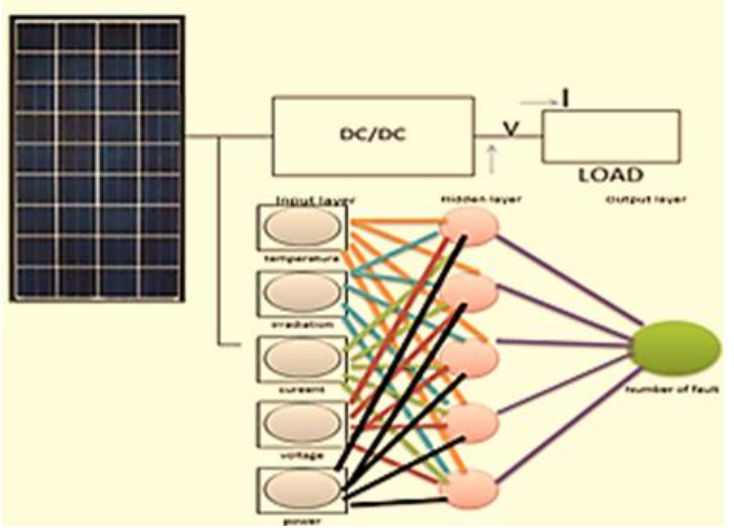

Fig.9 The block of the proposed ANN-based fault detection system.

\subsection{Fault Detection System}

The proposed ANN-based fault detection system has five inputs: temperature, solar radiation, voltage, current, and power at the maximum power point, as shown in Fig. 9. The ANN has been trained with the training dataset and tested from the remaining collected and simulated data. The result can be validated for the correct value of output denoting the fault status after the input dataset is applied to the proposed ANN-based fault detection system.

\section{APPLICATION AND OPERATION}

\subsection{Training of the ANN}

The ANN is trained using the training data set so that the weights are determined, and the ANN is formulated, as shown in Fig.10.

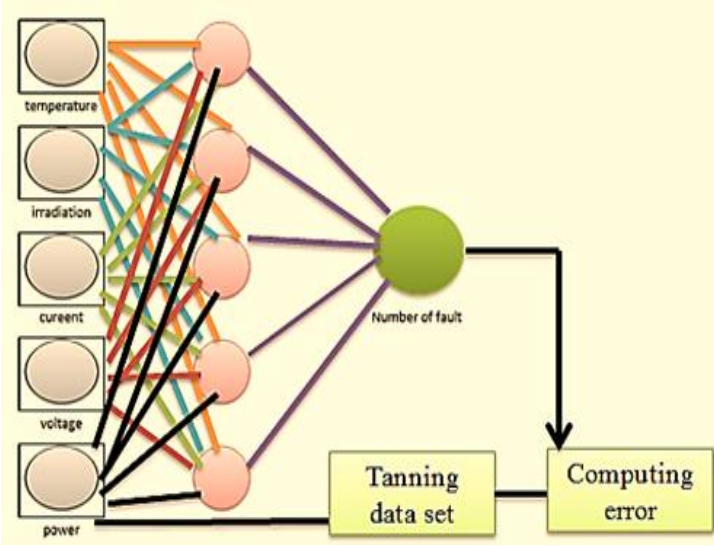

Fig.10 Adjustment of the ANN

The proposed ANN is trained at different solar radiations $(1000,800,600$, and 400) and different temperatures $(20,25,30,35,40$, and 45$)$. The training was done on every radiation with all temperatures and even on all operating cases (normal and faulty conditions).

\subsection{Testing of the ANN}

Table 9 addresses a sample of the test data set for ANN. The test data set is applied to the fault detection model. Fig. 11 shows the evolution of the performance error of the developed ANN-model. It is observed that the mean square error during the training process is about 10-3 (the best performance validation of the performance is at 0.22408 at epoch 9). This outcome points out that the weights and bias of the network are well adjusted, and the model could reproduce the output data with reasonable accuracy. The regression 
value is close to 1 , yet there is a perfect correlation

between targets and outputs [17]-[21].

Table 9. Sample of the test data set for ANN

\begin{tabular}{|c|c|c|c|c|c|c|c|c|}
\hline Temperature & 19 & 29 & 33 & 24 & 19 & 32 & 23 & 21 \\
\hline Irradiation & 900 & 950 & 350 & 390 & 970 & 750 & 790 & 810 \\
\hline$V_{\max }$ & 42.4198 & 40.625 & 39.639 & 33.319 & 34.4693 & 32.7502 & 22.6256 & 22.8026 \\
\hline$I_{\max }$ & 29.0197 & 30.7023 & 11.3629 & 12.6406 & 31.0958 & 24.2062 & 25.5156 & 26.1331 \\
\hline$P_{\max }$ & $1.23 \mathrm{E}+03$ & $1.25 \mathrm{E}+03$ & 450.413 & 421.171 & $1.07 \mathrm{E}+03$ & 792.7592 & 577.3035 & 595.9022 \\
\hline Fault No. & 0 & 0 & 0 & 1 & 1 & 2 & 3 & 3 \\
\hline Output of ANN & 0.0078 & 0.0091 & 0.0106 & 1.434 & 1.1051 & 1.5205 & 2.9283 & 2.931 \\
\hline
\end{tabular}

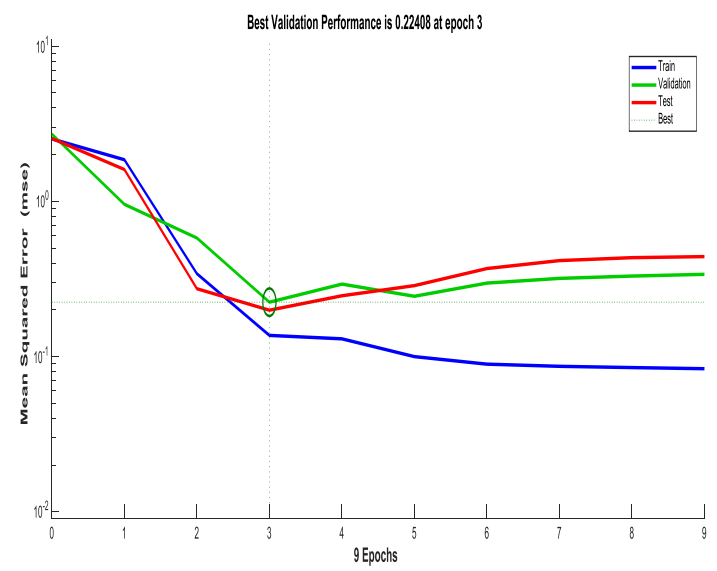

Fig.11 Performance test of proposed ANN fault detector

\subsection{Operation of the ANN}

When input data is applied to the proposed ANNbased fault detection system, the ANN's output is displayed as the number of faults, as shown in Fig. 12. Accordingly, the output is classified, as illustrated in Table 10, the type of the fault is determined. Therefore, it became easy to determine the type of occurred fault [22]-[27]. The inputs (x1) are in the order $\left\{\right.$ temperature, solar irradiance, $V_{\max }$ $\left., I_{\max }, P_{\max }\right\}$, and the output (y1) is a number from (0 to 3 ), each number specifies a specific type
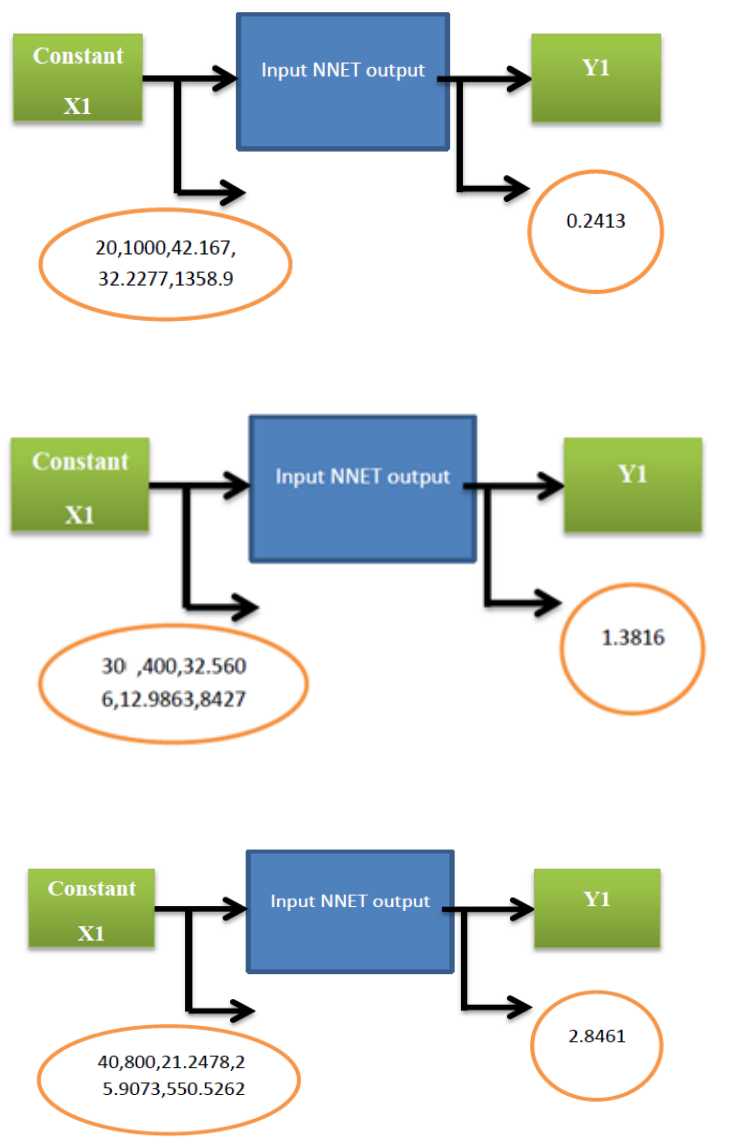

Fig. 12 Three examples show the operation of the proposed ANN-based fault detection system.

Of failure, number ' 0 ' denotes the normal operation, number ' 1 ' denotes a line to line fault with a small voltage difference, number ' 2 ' refers to a ground fault, and number ' 3 ' presents a line to line fault with a large voltage difference. 
Vol. 41, No.2. July 2022

Table 10.Operation of the proposed ANN

\begin{tabular}{|c|c|}
\hline Out of test data & Type of fault \\
\hline $0-0.6$ & 0 \\
\hline $0.7-1.6$ & 1 \\
\hline $1.7-2.5$ & 2 \\
\hline $2.6-3$ & 3 \\
\hline
\end{tabular}

\section{CONCLUSIONS AND FUTURE WORK}

A proposed ANN-based detection system has been designed and investigated to detect and classify faults in a PV power system. Results obtained through simulation showed the proposed system's efficiency to detect and classify the type of fault. This is achieved by collecting data like the voltage, current, and power at the maximum power point, in addition to the solar radiation and temperature. The proposed detection system proved its capability to operate at a different temperature, solar radiation, and applied faults with a quick response. Accordingly, when installing a PV power system, the proposed detector's presence will help in the protection process and reduce the PV outage periods and hence increase the PV power systems reliability. The future study includes monitoring the whole PV system, identifying the faulty section, and integrating it with the protective device to clear the fault.

\section{Appendix:}

\section{A) ABBREVIATIONS}

\begin{tabular}{|c|c|}
\hline BOO & build-own-operate \\
\hline EETC & $\begin{array}{c}\text { Egyptian Electricity } \\
\text { Transmission Company }\end{array}$ \\
\hline AFD & $\begin{array}{c}\text { Agence Française de } \\
\text { Développement }\end{array}$ \\
\hline JICA & $\begin{array}{c}\text { Japan International } \\
\text { Cooperation Agency }\end{array}$ \\
\hline NREA & New and Renewable \\
& Energy Authority \\
\hline
\end{tabular}

\begin{tabular}{|c|c|}
\hline PPA & $\begin{array}{c}\text { power purchase } \\
\text { agreement }\end{array}$ \\
\hline EPC & engineering, \\
& procurement, and \\
& construction \\
\hline
\end{tabular}

\section{REFERENCES}

[1] Padey, Pierryves, et al. "Understanding LCA results variability: developing global sensitivity analysis with Sobol indices. A first application to photovoltaic systems." Proceedings of the international symposium on life cycle assessment and construction civil engineering and buildings. Nantes, France: RILEM publications, 2012...

[2] Masson, Gaëtan, et al. "Global market outlook for photovoltaics 2013-2017." European Photovoltaic Industry Association: 12-32 (2013).

[3] Barnett, Allen, et al. "Solar-Electric Power: The US Photovoltaic Industry Roadmap." US Photovoltaic Industry Roadmap Steering Committee. http://www. sandia. gov/pv/docs/PDF/PV_Road_Map. pdf (2003).

[4] Surek, Thomas. "Progress in US photovoltaics: Looking back 30 years and looking ahead 20." 3rd World Conference onPhotovoltaic Energy Conversion, 2003. Proceedings of. Vol. 3. IEEE, 2003..

[5] Kirkegaard, Jacob F., et al. "Toward a sunny future? Global integration in the solar PV industry." Peterson institute for international economics working paper 10-6 (2010).

[6] Frankl, Paolo, et al. "Technology roadmap: solar photovoltaic energy." International Energy Association (2010).

[7] Simonyan, A. S., and A. M. Solntsev. "The International renewable energy agency (IRENA)." Международное п право 43.3: 61a-61a,(2010)

[8] ALHEJJI, Ayman; MOSAAD, Mohamed I. Performance enhancement of grid-connected PV systems using adaptive reference PI controller. Ain Shams Engineering Journal, 2020. 
[9] Jenitha, P., and A. Immanuel Selvakumar. "Fault detection in PV systems." Applied Solar Energy 53.3: 229-237, (2017)

[10] Chouder, A., and S. Silvestre. "Automatic supervision and fault detection of PV systems based on power losses analysis." Energy Conversion and Management 51.10: 19291937, (2010).

[11]Islam, Saif U1, et al. "Design of robust fuzzy logic controller based on the levenberg Marquardt algorithm and fault ride-through strategies for a grid-connected PV system." Electronics 8.4 : 429, (2019).

[12] ABED EL-RAOUF, M. Osama, et al. MPPT of PV-Wind-Fuel cell of off-grid Hybrid System for a New Community. In: 2018 Twentieth International Middle East Power Systems Conference (MEPCON). IEEE, p. 480-487, 2018.

[13] Aziz, Farkhanda, et al. "A novel convolutional neural network-based approach for fault classification in photovoltaic arrays." IEEE Access 8: 41889-41904, (2020).

[14] Made, Siva Ramakrishna, and S. N. Singh. "Online modular level fault detection algorithm for grid-tied and off-grid PV systems." Solar Energy 157: 349-364, (2017).

[15] Firth, Steven K., Kevin J. Lomas, and Simon J. Rees. "A simple model of PV system performance and its use in fault detection." Solar energy 84.4 624-635. (2010).

[16] Zhang, Jeff Jun, Kanad Basu, and Siddharth Garg. "Fault-tolerant systolic array based accelerators for deep neural network execution." IEEE Design \& Test 36.5: 44-53, (2019).

[17] Triki-Lahiani, Asma, Afef Bennani-Ben Abdelghani, and Ilhem Slama-Belkhodja. "Fault detection and monitoring systems for photovoltaic installations: A review." Renewable and Sustainable Energy Reviews 82: 2680-2692. (2018)

[18] Liu, Guangyu, and Weijie Yu. "A fault detection and diagnosis technique for solar system based on Elman neural network." 2017 IEEE 2nd Information Technology, Networking, Electronic and Automation Control Conference (ITNEC). IEEE, 2017.
[19] Mellit, Adel, Giuseppe Marco Tina, and Soteris A. Kalogirou. "Fault detection and diagnosis methods for photovoltaic systems: A review." Renewable and Sustainable Energy Reviews 91: 1-17, (2018).

[20] Wang, Zhijian, et al. "A novel method for intelligent fault diagnosis of bearing based on capsule neural network." Complexity 2019 (2019).

[21] Rao, Sunil, Andreas Spanias, and Cihan Tepedelenlioglu. "Solar array fault detection using neural networks." 2019 IEEE International Conference on Industrial CyberPhysical Systems (ICPS). IEEE, 2019.

[22] Zhu, Honglu, et al. "Fault diagnosis approach for photovoltaic arrays based on unsupervised sample clustering and probabilistic neural network model." Solar Energy 176: 395-405, (2018).

[23] Omran, Alaa Hamza, et al. "A novel intelligent detection schema of series arc fault in photovoltaic (PV) system based convolutional neural network." Periodicals of Engineering and Natural Sciences 8.3 :16411653, (2020).

[24] Pillai, Dhanup S., and N. Rajasekar. "A comprehensive review on protection challenges and fault diagnosis in PV systems." Renewable and Sustainable Energy Reviews 91 :18-40, (2018).

[25] Lin, Faa-Jeng, and Kuang-Chin Lu. "Design of fuzzy probabilistic wavelet neural network controller a nd its application in power control of grid-connected PV system during grid faults." 2016 IEEE International Conference on Fuzzy Systems (FUZZ-IEEE). IEEE, 2016.

[26] Gao, Wei, and Rong-Jong Wai. "A Novel Fault Identification Method for Photovoltaic Array via Convolutional Neural Network and Residual Gated Recurrent Unit." IEEE Access 8: 159493-159510, (2020).

[27] Kolla, Sri, and Logan Varatharasa. "Identifying three-phase induction motor faults using artificial neural networks." ISA transactions 39.4:433439, (2000). 


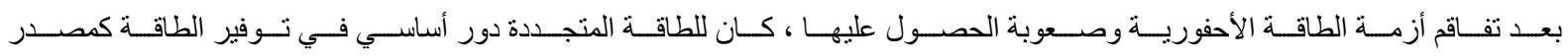

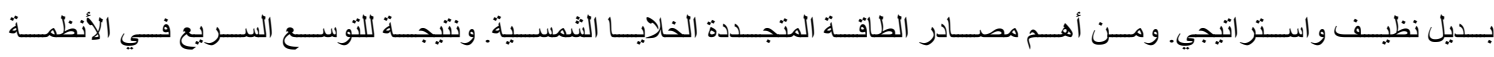

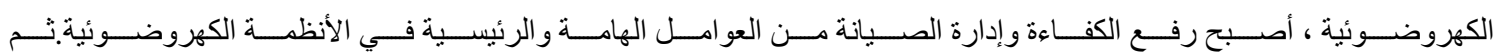

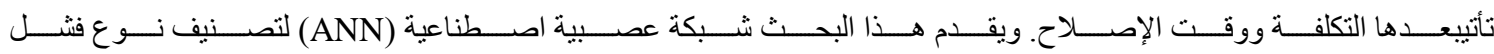

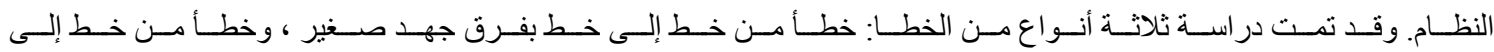

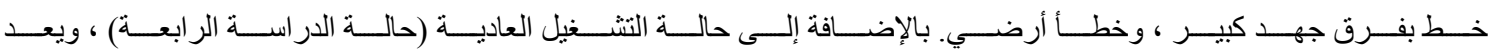

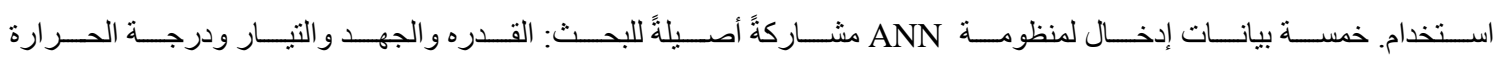

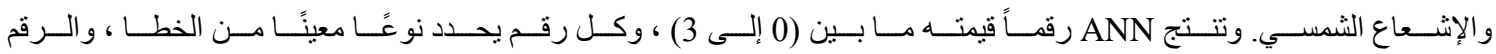

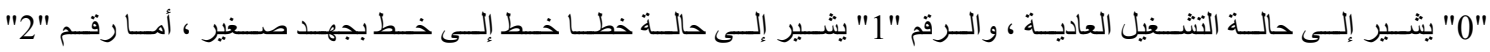

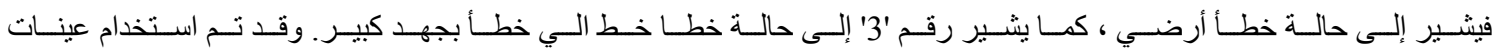

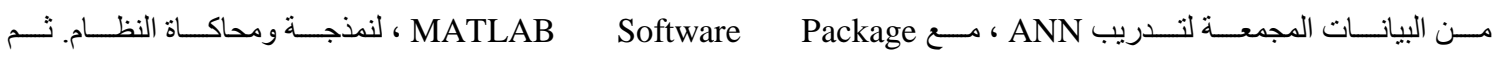

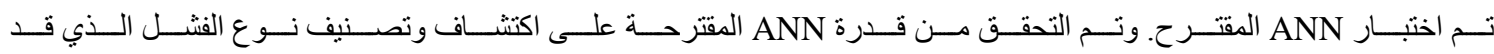

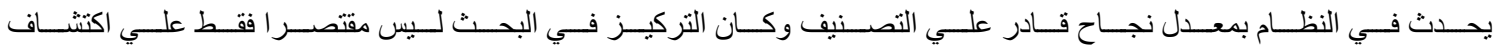
وجود خطا بل تحديد نوع الخطا وذلك يسهل في عمليه الصيانه ويقلل من الفقد ف الطاقه . 